\title{
PERILAKU NARSISTIK PADA ANAK PECANDU APLIKASI TIKTOK
}

\author{
Dita Efani, M. Arif Budiman S., M.Pd \\ Bimbingan \& Konseling, Fakultas Keguruan \& Ilmu Pendidikan, Universitas Pancasakti Tegal, \\ Jawa Tengah, Indonesia.
}

\begin{abstract}
Abstrak
Penelitian ini bermaksud untuk mengetahui gambaran dari perilaku narsistik, faktor dari dalam maupun dari luar yang menjadikan seorang anak menjadi candu terhadap aplikasi Tiktok sehingga muncul perilaku narsistik serta dampak yang ditimbulkan dari perilaku narsistik pada anak pecandu aplikasi Tiktok baik dampak pada dirinya, keluarganya, lingkungan sekitarmaupun pola belajar pada masa pendidikannya. Metode dalam penelitian menggunakan metode kualitatif dengan teknik dalam pengumpulan data menggunakan wawancara, observasi dan dokumentasi. Proses analisis data dilakukan dengan melalui tiga tahap yakni Reduksi data, Penyajian data, Penarikan kesimpulan. Hasil dari wawancara disimpulkan bahwa dari kesesuaian delapan indikator antara lain kesesuaian pola perfasiv, kesesuaian perasaan grandiose, kesesuaian terpreokupasi, kesesuaian keyakinan dirinya istimewa, kesesuaian minta dipuji, kesesuaian mengeksploitasi, kesesuaian kurang memiliki empati dan kesesuaian arogan. Indikator kesesuaian terbesar diantara delapan ada pada keinginan untuk mendapatkan pujian ketika seorang anak kecanduan bermain aplikasi Tiktok. Dari hal tersebut, dapat disimpulkan bahwa mendapatkan pujian menjadi hal yang sangat penting bagi anak pecandu aplikasi Tiktok.

Katakunci :Perilaku, Narsistik, Anak, Kecanduan, Aplikasi, Tiktok
\end{abstract}

\begin{abstract}
This study intends to find a picture of narcissistic behavior, internal and external factors that make a child addicted to the Tiktok application so that narcissistic behavior appears and the effects arising from narcissistic behavior in children addicted to the Tiktok application both the impact on himself, his family, the environment and learning patterns during his education. The method in this study uses qualitative methods with techniques in data collection using interviews, observation and documentation. The process of data analysis is done through three stages namely data reduction, data presentation, drawing conclusions. The interview result showed eight conformity indicators consisting pervasive pattern, grandiose feeling, being preoccupied, believing that he/she is special, demanding compliment, exploitive, having less empathy and arrogance. Of those conformity indicators, the demanding compliment is the greatest one required by the children addicted playing the Tiktok application. From this, it can be concluded that getting praise becomes very important for children addicted to the Tiktok application.
\end{abstract}

Key: Attitudes, Narcissistic, Children, Addicted, Application, Tiktok

\section{PENDAHULUAN}

Aplikasi Tiktok merupakan aplikasi yang sedang di gandrungi oleh seluruh kalangan. Tidak hanya di dunia, bahkan di Indonesia pun ikut terserang wabah joget asyik ala DJ dalam aplikasi tersebut. Aplikasi yang diluncurkan melalui laman play.google.com sendiri merupakan komunitas vidio secara umum yang didukung dengan musik. Melalui aplikasi tersebut, para pengunduh terutama bagi pembuat konten bisa mendapatkan kebebasan dalam mengekspresikan gaya serta kebolehannya dalam menari.Aplikasi Tiktok pertama kali diperkenalkan pada tahun 2016, sebuah aplikasi yang dikembangkan oleh developer asal tiongkok bernama ByteDance yang di dirikan oleh Zhang Yiming. Zhang Yiming merupakan Sarjana Software Engineering dan dikenal sebagai salah satu orang terkaya di Tiongkok menurut laporan Forbes pada tahun 2013, pria tersebut masuk dalam daftar 30 orang terkaya dengan umur dibawah 30 tahun yang juga pada saat itu menjadi pendiri aplikasi berita Toutiao untuk warga Tiongkok. Sejak pertama kali ada, aplikasi Tiktok diciptakan untuk generasi muda. Pada tahun 2018, Tiktok berhasil mencatatkan diri sebagai aplikasi paling banyak diunduh di App Store, Business Insider memprediksikan aplikasi Tiktok sudah diunduh sebanyak 45,8 juta kali. 
Dilansir pada katadata.com, hingga tahun 2019 kuartal III menurut Sensor Tower unduhan aplikasi Tiktok menempati urutan ketiga terbanyak untuk kategori non - gim jumlah unduhannya pada App Store dan Google Play Store menembus angka 176,5 juta unduhan. Dengan perolehan tingkat ketiga di negara asal sebagai aplikasi yang diunduh, India sebanyak 466,8 kali, di Cina mencapai 173,2 kali, Amerika Serikat dengan jumlah unduhan sebanyak 123,8 juta kali dan total keseluruhan perusahaan pengembang aplikasi tersebut memiliki 1,5 miliar pengguna secara global. Dengan total jumlah tersebut, aplikasi Tiktok sempat menempati tangga nomor dua aplikasi populer mengalahkan facebook dan instagram yang lebih dulu populer.

Perkembangan aplikasi Tiktok di Indonesia sendiri berawal dari merebaknya kasus Bowo seorang pengguna aktif Tiktok yang sempat menarik perhatian warga karena telah mengadakan Meet and Great dengan jumlah uang yang harus dikeluarkan untuk membeli tiket tidak main - main nominalnya. Berita tersebut kemudian Viral di akun sosial media Facebook dan Instagram sehingga membuat Bowo sebagai pemilik akun Tiktok tersebut mendapatkan pemblokiran akun hingga sekarang.

Hingga pada awal Juli, tepatnya 3 Juli 2018 aplikasi Tiktok untuk pertama kalinya mendapat teguran dan pemblokiran di Indonesia oleh Kominfo karena dinilai terlalu negatif untuk anak anak. Pemblokiran tersebut dilakukan berdasarkan pemantauan tim AIS Kominfo, Pelaporan dari Kementrian Pemberdayaan Perempuan dan Anak (Kemen PPA), Komisi Perlindungan Anak Indonesia (KPAI) dan juga dari masyarakat.Kendati demikian, setelah adanya pemblokiran tersebut akhirnya terjadilah pertemuan antara pihak Aplikasi Tiktok dengan Kominfo yang menghasilkan beberapa syarat misalnya dengan pembersihan konten negatif, menaikan batas minimal usia pengguna aplikasi dari 12 tahun menjadi 16 tahun hingga membuka kantor perwakilan di Indonesia sebagai bentuk komunikasi efektif jika kembali terjadi aduan terhadap aplikasi tersebut.Hingga penulis membuat tulisan ini, pengguna aplikasi Tiktok terus bertambah marak sejalan dengan keterlibatan artis atau public figure yang berlomba - lomba unjuk kebolehan dalam bermain Tiktok. Hal tersebut membuat demam pada aplikasi Tiktok semakin menjadi ditambah dengan penggunaan telepon genggam yang sudah mulai diberikan kepada anak sejak duduk dibangku sekolah dasar.

Tiktok pada awalnya merupakan aplikasi yang dibuat untuk menggali kreativitas para pengguna, dengan menggunakan video yang menarik dan lucu tentunya mengharuskan para pembuat kontennya agar kreatif.Dilansir cewekbanget.id, durasi video Tiktok yang pendek yakni 15 detik ternyata juga bisa menjadi alasan kedua aplikasi ini menarik untuk digunakan setelah dorongan kreativitas. Dengan durasi yang pendek, para pengguna didorong untuk dapat menyusun konsep dalam mengidentifikasi konten pilihan yang akan mereka buat jika masih belum menyukai konsep konten pilihan mereka bisa langsung melanjutkan pencarian konsep lain dengan cepat karena durasi waktu yang singkat sehingga tidak terlalu memakan banyak waktu.Alasan lain mengapa aplikasi Tiktok ini banyak diminati yakni menggunakan teknologi kecerdasan buatan (AI Lab) dari Jinri Toutiao dimana isinya adalah teknologi face recognition, body recognition dan $3 D$ rendering dengan dukungan full-screen sticker, dancing game, AR sticker dan $3 D$ coloring yang membuat betah para pengguna aplikasi tersebut.Dan hal terakhir yang menjadi alasan mendasar dari minat pengguna aplikasi Tiktok adalah adanya hashtag \#Challenge, hal tersebut membuat adanya daya saing antar para pengguna untuk menjadi yang paling sempurna dalam menampilkan konten - konten di aplikasi tersebut. Usaha menjadi yang paling sempurna dengan menerima tantangan menjadikan pengguna aplikasi tersebut menjadi Narsis untuk mendapatkan kepopuleran diantara pengguna aplikasi tiktok yang lain.Namun, berbagai alasan mengapa aplikasi ini begitu diminati di atas bagi penulis terdapat satu alasan kuat yang sangat mendasari yakni alunan DJ dalam musik aplikasi Tiktok dari lagu - lagu terbaru sehingga membuat para pengguna merasakan sensasi kecanduan untuk terus menari dan memainkan aplikasi tersebut meskipun hanya menjadi penonton.

Setiap hal yang diciptakan pasti memiliki dampak. Baik dampak terhadap diri sendiri maupun dampak yang melibatkan orang banyak. Berbicara tentang dampak, fikiran kita pasti tertuju dengan sesuatu hal yang merugikan. DampakmerugikandarikecanduanbermainaplikasiTiktoksepertimenjadipenyebabgenerasi era sekaranguntuksukabergoyang ria, membuang - buangwaktu, memakanbanyaktempat pada memory smartphone, individumenjadikurangdalamliterasiinformasisertamemilikipemikiran yang sempit. Padahal tidak demikian, dampak dibagi menjadi dua yakni selain merugikan juga menguntungkansepertikemunculankreatifitasindividu, saranahiburansertamengasahkemampuanmengedit video.

Setelah mengetahui dampak yang didapatkan dari bermain aplikasi Tiktok, faktanyanya dizaman sekarang bukannya berkurang justeru semakin merebak para pengguna aplikasi tersebut. Aplikasi yang diatur oleh Kominfo dengan batasan usia minimal pengguna adalah 16 tahun faktanya begitu banyak anak yang masih bangku di sekolah dasar yang telah menggunakan aplikasi 
Tiktok, bahkan beberapa diantaranya sengaja dikenalkan dengan aplikasi Tiktok tersebut melalui orang dewasa baik itu tetangga, saudara bahkan dari orang tua.

Anak - anak merupakan masa setelah tiga fase sebelumnya yakni prpenatal, masa bayi baru lahir serta masa bayi (Hurlock, 2017). Masa ini disebut - sebut sebagai masa setelah periode emas dan merupakan masa dimana seseorang belum mampu mengetahui benar dan salah dari suatu perbuatan dan peran orang dewasa lah yang semestinya berlaku untuk memfilter serta menjelaskan mana yang baik dilakukan sesuai norma yang berlaku dan mana yang bertentangan dengan norma yang berlaku di lingkungan tempat anak tinggal.

Hurlock, 2017:108 membagi masa anak - anak dengan sebutan awal masa kanak - kanak dan akhir masa kanak - kanak. Yang pertama yakni awal masa kanak - kanak, usia masa kanak - kanak awal dimulai pada dua sampai enam Tahun dengan sebutan awal masa kanak - kanak. Awal masa kanak - kanak disebut dengan usia problematis, menyulitkan atau mainan dan jika untuk dunia pendidikan masa awal kanak - kanak disebut dengan usia prasekolah secara psikologis usia ini dikenal dengan prakelompok, penjelajah atau usia bertanya. Pada masa ini yang bertanggung jawab paling banyak adalah orang dewasa sebagai orang yang akan menjelaskan setiap hal yang sedang terjadi. Pada masa ini juga biasanya muncul sejumlah pertanyaan diluar dari yang orang dewasa duga dan orang dewasa harus siap dengan memberi jawaban yang runtut tidak abstrak sesuai dengan realita yang terjadi sebab bila bertentangan dengan kenyataan yang dilihat oleh sang anak, anak tersebut tidak segan - segan untuk memberi pertanyaan yang sama namun dengan pola yang berbeda.

Kemudian, masa selanjutnya setelah masa awal kanak - kanak ialah akhir masa kanak - kanak dengan kisaran usia enam sampai tigabelas tahun. Akhir masa kanak - kanak merupakan periode dimana individu merasakan pendidikan di bangku sekolah dasar. Masa dimana individu mengeksplore segala yang ada dalam dirinya baik secara kognitif maupun secara motorik. Pada masa ini, manusia menjelajah dengan memaksimalkan perkembangan motorik dan menyenangi permainan, olahraga serta hiburan. Aktivitas - aktivitas tersebut tentunya diharapkan dapat memaksimalkan perkembangan keseimbangan anak untuk bisa menjalani tugas perkembangan di rentang usia akhir masa kanak - kanak. Perkembangan keseimbangan laki - laki dengan perempuan tentunya memiliki keberbedaan, hasil penelitian yang dilakukan pada jurnal nasional Perkembangan Keseimbangan pada Anak Usia 7 s/d 12 Tahun Ditinjau dari Jenis Kelamin dengan hasil penelitiannya yang menyatakan bahwa Berdasarkan grafik keseimbangan Statis anak laki-laki dan perempuan menyatakan adanya perbedaan antara keseimbangan Statis anatara anak laki-laki dan perempuan dimulai dari usia tujuh tahun sampai dengan usia sembilan tahun, anak laki-laki lebih baik keseimbangan Statisnya daripada anak perempuan sehingga pada saat penelitian anak laki-laki cenderung mendapatkan waktu ynag baik dalam melakukan tes keseimbangan.(Dhias, 2013:28). Pada umumnya, anak laki - laki lebih menyenangi aktivitas yang berkaitan dengan motorik dan jika dilihat secara langsung tidak menjadi hal yang aneh jika anak laki - laki bergerak lebih aktif dibanding dengan pergerakan anak perempuan. Misalnya saja dalam pemilihan permainan, anak laki - laki cenderung lebih memilih bermain petak umpet atau menjadi pahlawan dibanding anak perempuan yang kebanyakan akan memilih permainan boneka atau masak - masakan. Kendati demikian, ada satu karakter yang bisa ditarik sebagai benang merah dari perkembangan kanak - kanak baik itu jenis kelamin laki - laki maupun perempuan seperti yang disampaikan Abdul Alim, 2009 dalam jurnal nasional Aktivitas Fisik Olahraga untuk Pertumbuhan dan Perkembangan Siswa SD bahwa Karakter anak usia SD berkaitan dengan aktivitas fisik yaitu umumnya anak senang bermain, senang bergerak, senang beraktifitas kelompok dan senang praktik langsung. (Burhaen Erick, 2017:52). Karakteristik - karakteristik tersebut membuat manusia di masa kanak - kanak cenderung akan tertarik apabila diberikan suguhan permainan berupa "gadget". Gadget yang pada mulanya diberikan ketika anak sudah pada tahap pendidikan memasuki usia Sekolah menengan Dasar namun di era sekarang Gadget sudah diberikan pada anak yang masih duduk di bangku sekolah dasar dengan perkiraan pemberikan gadget dari orang tua ini terjadi ketika anak duduk dikelas empat sampai enam sekolah dasar. Begitu besar pengaruh gadget pada perkembangan karakter anak disampaikan hasil penelitian Chsuna, 2017:328 pada jurnal nasional Pengaruh Media Gadget pada Perkembangan Karakter Anak bahwa dizaman sekarang karakteristik anak yang senang bergerak dan berkelompok dengan interaksi sosial serta daya fikir dapat tersita karena gadget, namun karakteristik bermain dan senang praktik langsung anak semakin terasah dengan beberapa fitur yang ditampilkan oleh gadget.Karakteristik anak yang sedemikian rupa akhirnya membawa mereka mengenal pada fitur yang dibawa oleh gadget yaitu fitur permainan dan hiburan. Dua fitur tersebut bisa mereka dapatkan dari aplikasi Tiktok. Aplikasi yang merangsang anak untuk bergerak dengan alunan musik dan tentunya tantangan dari beberapa konsep konten akhirnya menjadi alasan yang mendasar mengapa aplikasi Tiktok membuat anak anak yang baru duduk di bangku kelas empat sekolah dasar merasakan kecanduan untuk terus 
bergerak, bermain dan membuat konten yang menarik di aplikasi tersebut.Pada saat anak sudah mulai kecanduan inilah peran orang tua harus segera mengembalikan anak sesuai dengan tugas perkembangan psikologinya, tidak hanya memaksimalkan perkembangan motorik saja namun secara psikologi perkembangan anak perlu untuk diseimbangkan. Tahap perkembangan psikologi anak belum harus mencapai tugas perkembangan tersebut, sebagai orang tua yang hidup di era milenials seperti sekarang akan dianggap "kolot" bila terus memaksakan kehendak dirinya tanpa memberikan kesempatan si anak hidup di zamannya, tentunya hidup dizaman sekarang sangat berisiko bahkan bersinggungan dengan ancaman perilaku narsistik dini yang disebabkan oleh bermain aplikasi tiktok tanpa kendali atau batasan tegas dari orang tua. Seperti layang - layang, terkadang terulur ketika sampai jauh ditarik agar tidak terbawa angin (Riyanto, 2006:5-8) . Pengaruh penggunaan gadget di zaman sekarang telah menarik perhatian. Fitur - fitur yang terdapat dalam gadget memberikan penawaran menggiurkan. Aplikasi tiktok menjadi fitur yang sedang digandrungi oleh kalangan termasuk pada kalangan usia anak sekolah dasar. Konten yang ditawarkan didalamnya serta didasarkan dengan karakteristik anak yang senang menghibur diri dan bergerak membuat aplikasi ini menjadi aplikasi andalan untuk unjuk kebolehan dalam menari dan menirukan gerakan yang ada dalam aplikasi tiktok tersebut.Fenomena anak bermain tiktok ini hadir dengan wujud nyata pada tahun 2018 silam, awal pertama kali kasus Bowo melambung sehingga membuat anak seusianya semakin penasaran dan gandrung dengan aplikasi ini. Sebuah jurnal mengangkat fenomena Bowo sebagai studi kasus dalam bergelut dengan dunia Tiktok. Peneliti menemukan bahwa Perilaku Bowo di pandang sebagai personal branding dengan memiliki tujuh konsep mulai dari spesialisasi, kepribadian, perbedaan, terlihat, kesatuan, keteguhan hingga nama baik. Personal branding bukanlah sesuatu yang instan melainkan harus didasari kenyataan dalam kehidupan aktivitas yang memperkuat pembentukan personal branding. Susilowati, 2018:184. Fitur aplikasi tiktok akan semakin membuat individu harus lebih narsis yakni karena adanya dukungan dari sosial media, tingkat unggahan pada sosial media dan jumlah menyukai atau disebut dengan like ataupun love lalu komentar yang di dapat dari sosial media membuat anak tingkat sekolah dasar sudah merasakan haus akan narsis sejak dini. Beberapa jurnal mengungkapkan perilaku yang muncul akibat dari fitur dalam gadget seperti pada pengguna sosial media facebook memiliki tingkat narsistik sedang yaitu $44 \%$ dengan jumlah orang 22 mengindikasikan pengguna facebook cenderung memiliki sifat dan mental narsis dengan jumlah jejaring sosial pertemanan sekaligus komentar yang berusaha untuk mempromosikan diri serta kuantitas pertemanan dirinya. Kristanto S, 2012:45, kemudian disampaikan pada jurnal lain tentang kecenderungan sosial media

Manusia hakikatnya dalam mengarungi perjalanan hidup tidak lepas dari dua hal, yakni kehidupan atas dirinya sendiri dan kehidupan dengan lingkungan sosial. Diri manusia yang dipandang unik dan begitu kompleks menyita curahan perhatian dan usaha yang besar untuk mempelajari arti jati di dalam dirinya terlepas hanya mampu mengetahui pada sudut pandang tertentu dan tetap membutuhkan pengamatan dari sudut pandang luar dalam hal ini yakni lingkungan sosial. Diri manusia dan lingkungan merupakan suatu kesatuan yang saling berkaitan dengan adanya jalinan interaksi. Interaksi sosial yang dibangun merupakan suatu jalinan yang mendasarkan pada suatu tindakan. Tindakan dihasilkan dari stimulus dan respon. Stimulus yakni berupa perilaku baik verbal maupun non verbal, pun demikian dengan respon. Perilaku manusia digolongkan menjadi baik dan buruk yang seluruhnya didasarkan pada relatifitas. Relatifitas artinya bergantung kepada dampak yang diterima dari atau oleh individu.Perilaku manusia banyak digali keberadaannya melalui penelitian, penelitian dilakukan untuk mengukur pola yang timbul ketika manusia berinteraksi yang kemudian bidang ilmunya disebut dengan studi perilaku. Studi perilaku merupakan pendekatan holistik dari koordinasi seperangkat pengetahuan berkaitan dengan perilaku manusia (Maufur, 2012:5). Studi perilaku tersebut kemudian memperoleh hasil perilaku berasal dari internal dan eksternal. Perilaku atas aktivitas dalam tubuh misalnya saja berfikir dikategorikan masuk dalam golongan perilaku internal, sedangkan aktivitas yang muncul dalam diri misalnya saja emosi, gugup akibat dari pengaruh lawan bicara masuk kedalam golongan perilaku eksternal. Bukan hanya itu, dalam studi perilaku membagi kategori perilaku normal dan abnormal. Perilaku normal merupakan suatu perilaku yang dipandang umum oleh khalayak dan perilaku abnormal tersendiri berarti apabila manusia melalukan sesuatu yang bertentangan dengan norma yang ada di khalayak umum. Kendati demikian, perilaku normal dan abnormal ini masih menyisakan kerelatifitas didalamnya terutama pada perilaku abnormal. Durrand, 2007 merujuk pada DSM V memberikan kontribusi tentang pandangannya terhadap perilaku abnormal, perilaku abnormal ini masuk pada kategori suatu gangguan yang teruji secara klinis tanpa adanya pendapat pribadi. Perilaku abnormal atau gangguan memiliki beberapa jenis misalnya gangguan makan, gangguan seksualitas dan identitas gender, gangguan terkait substansi dan pengendalian impuls, gangguan kepribadian, 
gangguan psikotik lainnya sampai gangguan perkembangan dan kognitif. Gangguan yang terjadi pada fenomena aplikasi tiktok masuk pada kategori gangguan narsistik.

Perilaku Narsistik merupakan suatu gangguan kepribadian. Kepribadian tersendiri antara manusia yang satu dengan yang lain memiliki perbedaan yang diantaranya tidak bisa sama satu dengan yang lain sehingga menjadikan manusia tersebut unik. Kepribadian tersendiri mencakup perilaku, tanggapan emosi serta pola fikir yang kategorinya mencakup pantas dan tidak pantas atau merusak. Dalam gangguan kepribadian ini, perilaku, tanggapan emosi serta pola fikir yang muncul adalah tidak sesuai dengan norma atau tidak pantas serta merusak bagi diri manusia tersebut maupun merusak bagi lingkungan sosialnya. Pengaruh kepribadian narsistik ini seperti yang disebut diatas memiliki pengaruh terhadap perilaku, pola fikir serta tanggapan emosi. Sebuah jurnal penelitian mengungkapkan hasil pengaruh perilaku narsistik terhadap perilaku dan respon emosional dengan hasil narsistik berpengaruh pada emosi negatif (Nugraheni Hariyanti \& Wahyuni Salamah, 2016:63) . Begitu berpengaruhnya narsistik terhadap kehidupan dibuktikan dengan penelitian terhadap hubungan seseorang kepada yang lain dengan hasil Narcissistic Personality Inventory (NPI): The latest form was standardized in Turkish and validity and reliability study was performed by Atay (29). It is composed of 6 subscales as authority (NA), exhibitionism (NI), exploitation (NE), selfsufficiency (NSS), demanding (ND), and superiority (NS). Each item in the scale had two proposal and it was requested from participants to mark the one which was most suitable for them. According to answer key, one proposal received 0 point, and the other 1 point. Atay reported that Cronbach's alpha value was 0.63 in safety analysis of the 16-item form (29)(Kalyon Ayse, 2016). Narsistik berasal dari kata Narsis atau dalam bahasa umum narsis merupakan suatu perilaku ingin terlihat lebih menonjol dari yang lain. Hal tersebut diungkapkan oleh beberapa jurnal yang menyatakan bahwa Narsis merupakan salah satu penyimpangan kepribadian mental seseorang di mana orang tersebut memiliki perasaan yang berlebihan bahwa dirinya lah yang paling penting, dan menginginkan untuk selalu dikagumi. (Engkus, 2017:124). Seseorang yang sangat ingin dikagumi akan membuat perilaku yang memberi pengaruh baik bagi dirinya maupun bagi lingkungan. Pengaruh ini bisa berupa dampak, adapun dampak seseorang berperilaku narsistik terdapat dalam sebuah jurnal penelitian dengan hasil Dampak negatif dari perilaku narsistik terhadap harga diri akan membuat harga diri individu tersebut semakin rendah, sebaliknya semakin tinggi harga diri dari individu akan semakin menekan perilaku narsistik Santi Novi Nitya 2017:29. Demikian perlunya seseorang mempertahankan harga dirinya agar terhindar dari perilaku narsistik yang masuk pada kategori sebuah gangguan kepribadian.Seseorang memiliki perilaku tertentu sudah pasti memiliki sebab. Sebab yang dengan kata lain disebut dengan faktor memiliki beberapa sumber, yakni dari internal dan dari sumber ekternal. Sumber internal merupakan sumber yang berasal dari dalam diri individu tersebut, sebaliknya sumber eksternal merupakan faktor penyebab yang bersumber dari luar diri individu misalnya saja tekanan lingkungan dan perkembangan zaman. Gangguan Kepribadian narsistik dapat disebabkan oleh dua faktor yakni Faktor internal Faktor internal dari narsistik meliputi; Pola pervasif dari grandiositas dan kebutuhan untuk dipuji dan empati yang bermula pada masa dewasa awal. Pola pervasif merupakan kelompok kondisi psikiatri berhubungan dengan harapan antara keterampilan sosial, perkembangan bahasa dan perilaku tidak berkembang sesuai atau hilang pada masa anak - anak awal sedangkan grandiositas merupakan kata lain dari delusi, orang yang mengalami delusi sering meyakini hal - hal yang tidak sesuai dengan kenyataan, Perasaan grandiose bahwa dirinya orang yang penting, misalnya berkaitan dengan narsistik ini individu tersebut merasa memiliki talenta yang luar biasa, Terpreokupasi dengan fantasi - fantasi tentang kesuksesan, kekuasaan, kecerdasan, kecantikan atau cinta ideal yang tanpa batas., Keyakinan bahwa dirinya "istimewa" dan hanya dapat dipahami oleh atau seharusnya hanya berhubungan dengan orang - orang istimewa lain atau orang - orang yang berstatus tinggi, Minta di puji secara eksesif, Mengeksploitasi orang lain untuk mencapai tujuannya, Kurang memiliki empati, Sering iri terhadap orang lain atau percaya bahwa orang lain iri kepadanya, Bersikap arogan (Durand \& Barlow, 2007). Bersamaan dengan faktor internal, Faktor eksternal selalu menyajikan hal yang dapat memberi pengaruh terhadap situasi dari kondisi narsistik berasal dari tekanan lingkungan. Tekanan lingkungan yang diiringi dengan perkembangan zaman yang melesat ini sangat dengan mudah mempengaruhi individu dalam berkehidupan sosial, seseorang semakin terdorong untuk menjadi yang paling menonjol sesuai dengan perkembangan zaman yang sedang ramai.

Faktor lain disebutkan bahwa The process of constructing self image arises internal and external conflicts. Teens have eager desire and curiosity to construct self image to set their own way of life. Narcissistic instinct arises due to the lack of mother-daughter attachment in maturing process. Abandonment feeling leads Connie to frustration. To be accepted, she splits into another different personality. Therefore, the nature of parental role determines child's self-image construction in their social and psychological well-beings. (Sartika, 2017)Dengan demikian bisa dilihat bahwa peran ikatan yang kurang terjadi antara orang tua dan anak bisa 
memunculkan perilaku narsistik.Gangguan Kepribadian Narsistik termasuk dalam gangguan kepribadian klaster B dimana salah satunya adalah dramatis, emosional atau eratik yang melibatkan pola pervasif dari grandiositas dalam fantasi atau perilaku. Perilaku tersebut termasuk dalam membutuhkan pujian dari seseorang dan kurang memiliki empati (Durand \& Barlow, 2007). Dramatis merupakan perilaku seseorang yang sesuai dengan kepribadian dan individu yang melakukan perilaku tersebut berdasarkan pada pergolakan didalam dirinya terutama pergolakan jiwa. Sedangkan emosional atau eratik yang melibatkan pola pervasif merupakan kelompok kondisi psikiatrik dimana adanya kesenjangan antara keterampilan sosial, perkembangan bahasa dan perilaku pada masa anak - anak awal. Perilaku pervasif yang terjadi pada anak - anak awal ini cenderung membuat anak - anak khususnya pada tingkat sekolah dasar menjadi gandrung terhadap sesuatu hal yang menarik perhatian. Misalnya saja pada aplikasi tiktok, mereka akan dengan mudah tertarik terhadap aplikasi yang menyajikan fitur dan musik yang begitu menarik ini.Sebuah studi menuturkan bahwa bentuk narsisme siswa dapat dikenali dengan cara egoism, sadism, cuek, ingin menguasai, memiliki perkumpulan sendiri dan ingin dipuji. Dan faktor penyebabnya adalah perilaku memperhatikan dirinya dan menganggap bahwa dirinya sangat penting juga unik. (Rudi, 2017:147-148). Perilaku Narsistik pada anak siswa Sekolah Dasar bukanlah suatu hal yang berlebihan jika itu juga terjadi pada kehidupan nyata seorang siswa. Sayangnya, hal tersebut hanya terjadi pada akun tiktoknya saja sedangkan diluar sekolah, narsis ini tidak berlaku ketika sang anak berada dalam lingkungan sekolah. Bahkan, ada tingkat kesenjangan antara dunia sekolah dengan dunia aplikasi Tiktok. Lebih parah lagi, Siswa sekolah dasar yang semestinya belum mengenal dunia percintaan namun dengan adanya aplikasi tersebut membuat akses terhadap romansa cinta semakin mudah.Melalui penelitian kali ini, penulis ingin menyampaikan bahwa pentingnya keseimbangan yang dibangun antara perilaku narsis diimbangi dengan rasa kepercayaan diri yang mumpuni. Tidak hanya ketika siswa Sekolah Dasar memainkan aplikasi Tiktok, namun juga ketika menjalani pembelajaran dalam kelas yang sifatnya maju dan mengemukakan pendapat di hadapan teman kelas.

Dengan demikian, melalui penelitian ini diharapkan dapat mengetahui gambaran dari perilaku narsistik pada anak pecandu aplikasi Tiktok, faktor - faktor apa saja yang menjadikan seorang anak pecandu aplikasi Tiktok memiliki perilaku narsistik serta dampak yang terjadi pada anak pecandu aplikasi Tiktok yang memiliki perilaku narsistik terutama pada dirinya, kehidupan di lingkungan keluarga, sosial dan pola belajar.

\section{METODE PENELITIAN}

Penelitian penulis kali ini menggunakan pendekatan kualitatif deskriptif, kualitatif deskriptif merupan suatu analisa data yang digunakan untuk menggambarkan atau mendeskripsikan data yang telah diperoleh sebagaimana adanya tanpa bermaksud membuat kesimpulan yang berlaku untuk umum atau general (Sugiyono, 2017). Menurut (Nurul, 2009) penelitian deskriptif merupakan penelitian yang diarahkan guna memberikan gejala - gejala, fakta - fakta atau kejadian - kejadian secara sistematis dan akurat mengenai sifat - sifat dari populasi tertentu.Menurut (Mahmud, 2011) penelitian deskriptif merupakan penelitian yang diupayakan untuk mencandra atau mengamati permasalahan secara sistematis dan akurat mengenai fakta atau sifat objek tertentu. Dengan demikian, penulis dapat menyimpulkan bahwa penelitian deskriptif ini merupakan suatu penelitian yang digunakan untuk menggambarkan gejala, sifat, fakta atau suatu kejadian secara sistematis.Penulis memilih pendekatan tersebut dengan alasan karena penulis ingin mendeskripsikan atau menggambarkan bagaimana sebenarnya perilaku narsistik pada anak pecandu aplikasi Tiktok. Pendekatan ini juga dipilih karena penulis belum memperoleh bukti secara nyata faktor dan dampak dari pengguna yang kecanduan aplikasi Tiktok yang mempengaruhi tingkat kepercayaan diri pengguna pada aplikasi Tiktok dan lingkungan kehidupan yang nyata terutama pada kalangan siswa sekolah dasar yang notabenenya adalah masih dalam fase anak - anak. Selain hal tersebut, metode penelitian ini memungkinkan penulis mengumpulkan data dan menyesuaikan dengan konteks, karena penelitian ini relevan menggunakan metode kualitatif.Menurut Sugiyono (2017:9) metode penelitian kualitatif adalah metode penelitian yang berlandaskan pada filsafat postpositivisme, digunakan untuk meneliti pada konsidi obyek yang alamiah, (sebagai lawannya adalah eksperimen) dimana peneliti adalah sebagai instrumen kunci, teknik pengumpulan data dilakukan secara triangulasi (gabungan), analisis data bersifat induktif/kualitatif dan hasil penelitian kualitatif lebih menekankan makna pada generalisasi. Bogdan dan Tylor dalam Moleong, 1990 pada buku Metodologi Penelitian Sosial dan Pendidikan mengungkapkan bahwa penelitian kualitatif adalah prosedur penelitian yang menghasilkan data deskriptif berupa kata - kata tertulis atau lisan dari orang - orang dan perilaku yang dapat diamati (Nurul, 2009) ditambahkan dari Mahmud, 2011:29 penelitian kualitatif mempergunakan data yang dinyatakan secara verbal dan kualifikasinya bersifat teoritis. Dalam penelitian tidak lepas dari populasi dan sampel jika pada kualitatif istilah adalah 
social situation dan Narasumber. Populasi dan sampel dalam penelitian merupakan sumber data, artinya sifat - sifat atau karakteristik dari sekelompok subjek, gejala atau objek (Nana, 2013). Populasi menurut Sugiyono (2017:80-81) merupakan wilayah generalisasi yang terdiri atas: obyek/subyek yang mempunyai kualitas dan karakteristik tertentu yang ditetapkan oleh peneliti untuk dipelajari dan kemudian ditarik kesimpulannya sedangkan Sampel merupakan bagian dari jumlah dan karakteristik yang dimiliki oleh populasi tersebut. Menurut Nurul (2009:116-119) populasi merupakan seluruh data yang menjadi perhatian peneliti dalam suatu ruang lingkup dan waktu yang ditentukan sedangkan sampel sering diartikan sebagai bagian dari populasi. Menambahkan dari Mahmud, 2011:155 populasi dan sampel menunjukan seberapa luas jangkauan kesimpulan yang diharapkan atau generalisasi konklusi penelitiannya.Proses penelitian ini dilakukan antara bulan Maret hingga Juni dimana bulan - bulan tersebut merupakan masa berbarengannya dengan wabah pandemi COVID - 19 yang membuat penggunaan aplikasi Tiktok meningkat tajam sebagai alternatif hiburan ditengah himbauan untuk Stay At Home. Penelitian ini dilakukan dengan teknik pengambilan sampel snowball sampling techniqur di wilayah kabupaten Brebes, Kecamatan Brebes, Desa Kaligangsa Kulon Rt 001/002 tepatnya sekitar Sekolah Dasar yakni SD Negeri Kaligangsa Kulon 02dengansubjek RA, RZN dan SS.

Penelitian ini berkaitan dengan suatu variabel, variabel penelitian menurut Sugiyono (2017:39) merupakan suatu atribut atau sifat atau nilai dari orang, obyek atau kegiatan yang mempunyai variasi tertentu yang ditetapkan oleh peneliti untuk dipelajari dan kemudian ditarik kesimpulannya. Demikian dalam hal ini variabel yang berkaitan dengan penelitian penulis yakni perilaku narsistik dimana pengertian dari perilaku narsistik merupakan gangguan kepribadian dimana seseorang akan menganggap dirinya penting dan harus dipuji secara berlebihan. Perilaku narsistik ini terjadi karena beberapa faktor yang disampaikan oleh (Durand \& Barlow, 2007) dikategorikan faktor internal dan faktor eksternal, dan dari pola asuh orang tua yang disampaikan pada jurnal (Sartika, 2017)tentunya berdampak pada rasa kepercayaan diri dan lingkungan terutama kaitannya dengan anak yang duduk di bangku Sekolah Dasar.Teknik pengumpulan data penulis menggunakan tehnik wawancara, observasi dan dokumentasi. Wawancara merupakan teknik pengumpulan data dengan cara tanya jawab yang dilakukan secara lisan dan dengan sistematis untuk mencapai tujuan dari penelitian (Anwar, 2014). Setelah memperoleh data dan informasi, langkah selanjutnya dalam penelitian ini adalah melakukan analisis data dalam rangka menemukan makna temuan. Data diperoleh dari berbagai sumber dengan menggunakan triangulasi. Proses analisis data dilakukan dengan melalui tiga tahap yakni Reduksi data, Penyajian data, Penarikan kesimpulandari ketiga proses tersebut yang akan penulis gunakan adalah penarikan kesimpulan guna memperoleh bukti - bukti kuat yang mendukung penelitian.

\section{HASIL}

Hasil penelitian yang dilakukan di lingkungan Rt 001/002 Kaligangsa kulon, Kecamatan Brebes, Kabupaten Brebes. Lokasi dalam penelitian dilakukan di satu rumah untuk pengumpulan data dengan wawancara secara bersamaan karena narasumber merupakan teman satu permainan di lingkungan tersebut dan narasumber yang lain merupakan salah satu keluarga dari narasumber utama penelitian kali ini sehingga peneliti memustuskan untuk melakukan wawancara secara bersamaan di satu rumah salah satu narasumber dimana rumah tersebut merupakan tempat biasanya narasumber pertama bermain atau membuat vidio untuk konten di aplikasi Tiktok.

Lokasi rumah tersebut yaitu di Jl. Pemuda No. 04 Rt 001/002 desa Kaligangsa Kulon, kecamatan Brebes, Kabupaten Brebes. Rumah dari narasumber satu dengan yang lain masih berdekatan tidak berjarak mereka bertetangga namun jika dilihat dari lokasinya rumah yang digunakan untuk pengumpulan data ini lebih luas dari lokasi rumah narasumber primer sehingga memungkinkan adanya keleluasaan untuk melakukan pengumpulan data, juga ketika peneliti melihat lokasi tersebut tingkat kebisingan dari sekitar lebih minim karena lumayan jauh dari jalan raya tepatnya berjarak satu rumah dan trotoar ke arah selatan sehingga bising dari hiruk pikuk jalan raya bisa diredam selama melakukan sesi perekaman, kebisingan dari lingkungan sekitar pun tidak seramai dari rumah karena lumayan jauh dari jalanan utama desa tepatnya berada ditengah dan jarang dilalui lalu lalang orang desa tersebut hanya beberapa tetangga saja yang berkumpul untuk sekedar berbincang membicarakan tentang hal - hal yang sedang banyak dibicarakan baik di lingkungan desa maupun lingkungan nasional misalnya saja saat itu beberapa sedang berbincang tentang COVID-19 dan Sekolah Dasar yang belum pasti kapan berangkatnya sehingga membuat para orang tua meresahkan biaya data atau Internet untuk mendukung Sekolah dari rumah anak anaknya.

Adapun subjek yang digunakan dalam penelitian ini merupakan siswi yang masih duduk di bangku Sekolah Dasar, lokasi peneliti yang dekat dengan Sekolah Dasar yang akan dijadikan sampel memungkinkan peneliti tidak perlu datang ke Sekolah sehingga dapat memudahkan 
pelaksanaan penelitian kali ini hanya dengan datang dirumah bagian dari sampel penelitian. Untuk sampel penelitian, peneliti menggunakan tiga narasumber sebagai sampel penelitian. Narasumber pertama merupakan narasumber primer untuk memperoleh informasi dari penelitian yang dilakukan yakni seputar perilaku dirinya ketika kecanduan bermain Tiktok apakah ada indikasi ke arah narsistik demikian, untuk narasumber kedua dan ketiga menjadi narasumber sekunder atau pendukung menjadi sumber lain juga untuk memperkuat dari pernyataan yang disampaikan oleh narasumber primer. Adapun narasumber tersebut dengan inisial RA sebagai narasumber primer seorang siswi di SDN Kaligangsa Kulon 02, RZN sebagai narasumber sekunder atau pendukung seorang siswi yang bersekolah di Sekolah Dasar yang sama dengan narasumber primer yakni di SDN Kaligangsa Kulon 02 juga sebagai teman sebaya yang sering bermain dengan narasumber primer, SS sebagai narasumber pendukung yang merupakan bagian dari anggota keluarga narasumber primer yakni kakak dari narasumber primer.

Tujuan dari penelitian ini untuk mengetahui perilaku yang muncul ketika seorang siswa Sekolah Dasar mengalami kecanduan aplikasi Tiktok, faktor - faktor yang mempengaruhi serta dampaknya dari hasil wawancara dengan tiga narasumber mengenai perilaku narsistik pada pengguna aplikasi Tiktok dapat disimpulkan bahwa faktor perilaku narsistik muncul di kalangan anak yang menggunakan aplikasi Tiktok yang terdapat delapan indikator antara lain kesesuaian pola perfasiv, kesesuaian perasaan grandiose, kesesuaian terpreokupasi, kesesuaian keyakinan dirinya istimewa, kesesuaian minta dipuji, kesesuaian mengeksploitasi, kesesuaian kurang memiliki empati dan kesesuaian arogan.

Hasil wawancara kesesuian indikator faktor perilaku narsistik pada anak pecandu aplikasi Tiktok dibuktikan dengan beberapa pernyataan yang memperkuat adanya beberapa faktor yang memicu perilaku narsistik seorang anak menjadi pecandu aplikasi Tiktok. Narasumber primer menyatakan bahwa keinginan untuk mendapatkan pujian menjadi faktor dirinya senang ketika bermain aplikasi Tiktok hal tersebut dibuktikan dengan dirinya yang senang apabila dipuji hal tersebut di sampaikan langsung oleh narasumber primer pun didukung dengan narasumber pendukung dimana narasumber ini datang dari keluarga narasumber primer yang menyatakan bahwa narasumber primer senang dipuji serta tidak ragu untuk menunjukan hasil vidio yang telah dibuat narasumber primer untuk mendapatkan pujian dari keluarga dan sekitar narasumber primer. Hal tersebut sesuai dengan yang disampaikan dalam jurnal The process of constructing self image arises internal and external conflicts. Teens have eager desire and curiosity to construct self image to set their own way of life. Narcissistic instinct arises due to the lack of mother-daughter attachment in maturing process. Abandonment feeling leads Connie to frustration. To be accepted, she splits into another different personality. Therefore, the nature of parental role determines child's self-image construction in their social and psychological well-beings. (Sartika, 2017) bahwa peran komunikasi orang tua penting terhadap anak sehingga narsistik yang berlebihan untuk menuai pujian berlebih juga dapat diminimalisir.

PEMBAHASAN

Perilaku narsistik yang muncul dari kecanduan bermain aplikasi Tiktok tidak ubahnya menyerang segala kalangan, termasuk pada siswi Sekolah Dasar yang tak luput dari hal tersebut. Siswi Sekolah Dasar yang menyenangi aktifitas motorik serta hal - hal menarik menjadi alasan besar mengapa aplikasi Tiktok ini begitu digemari. Bukan hanya hal tersebut, ada beberapa faktor lain yang member pengaruh terhadap perilaku narsistik pada anak pecandu aplikasi Tiktok seperti dorongan dari teman sebaya yang juga memainkan aplikasi tersebut. Kesesuaian faktor yang lain dimana narasumber menyatakan narasumber merasakan menjadi penari ketika bermain aplikasi dan hal tersebut sesuai dengan faktor dimana perilaku narsistik bisa muncul karena orang merasa istimewa atau memiliki bakat. Kesesuaian lain ditunjukan dengan ketika narasumber membuat vidio dan hasilnya kurang bagus lalu teman dari narasumber primer melihat, maka yang terjadi adalah narasumber primer akan marah ketika mendapatkan suatu ledekan dari teman - temannya demikian pula ketika teman - teman dari narasumber yang ikut bermain aplikasi Tiktok apabila ada hal yang tidak bagus dalam membuat vidio untuk di upload pada akun Tiktok, Narasumber akan meminta membuat ulang vidio sampai vidio yang dibuat bagus untuk di upload hal tersebut disampaikan pula oleh kakak sebagai narasumber pendukung memperkuat dengan menyatakan bahwa narasumber primer akan marah ketika diganggu dalam membuat vidio. Kendati demikian seorang anak pecandu aplikasi Tiktok masih memiliki rasa malu ketika dirinya dihadapkan di lingkungan sekolahnya berbanding terbalik ketika dihadapkan dengan kamera ketika bermain aplikasi Tiktok pihak keluarga pun menyayangkan hal demikian dan mengharapkan narasumber primer bersikap sewajarnya anak sekolah yang menyenangi proses belajar. Dari beberapa kesesuaian indikator dengan demikian perilaku narsistik pada anak pecandu aplikasi Tiktok selalu hadir dengan faktor - faktor seperti yang sudah peneliti sampaikan, dimana faktor tersebut yang membuat perilaku narsistik muncul. Namun dari banyaknya kesesuaian indikator yang paling relevan sebagai 
faktor yang menjadikan munculnya perilaku narsistik muncul pada individu adalah keinginan untuk mendapatkan pujian dari orang banyak yang dilakukan secara sengaja, baik itu pujian secara langsung dari orang terdekat maupun dari orang yang sama - sama bermain aplikasi Tiktok. Alasan demi mendapatkan sebuah pujian ini juga diperkuat dengan artikel yang memuat sebuah pujian menjadi indikasi seseorang mengalami narsistik, dilansir dari 1 setidaknya ada lima hal yang dapat mengindikasikan seseorang mengidap kepribadian narsistik salah satu indikasinya adalah haus akan pujian dan menjadi tagline utama dari artikel tersebut, hal ini sejalan dengan merebaknya fenomena selfie atau berswafoto menggunakan kamera depan dan vidio konten hasil dari pengguna aplikasi Tiktok. Dampak dari perilaku narsistik kecanduan aplikasi Tiktok bukan hal sepele, hal tersebut berdampak pada diri anak tersebut yang kehilangan rasa empati dengan sikap memaksa dan marah secara berlebihan apabila keinginannya tidak terpenuhi, kehilangan minat dalam belajar menjadikan keluarga anak tersebut merasa kewalahan dalam menangani serta lingkungan sekitar yang memandang kurang baik terhadap anak tersebut karena terlalu haus atas pujian.

\section{KESIMPULAN}

Anak pecandu aplikasi Tiktok pada dasarnya hanya melakukan kegiatan sesuai dengan tahap perkembangannya yakni aktif dalam gerak motorik serta memiliki ketertarikan lebih terhadap suatu hal yang dianggapnya menarik, bermain aplikasi Tiktok menjadi candu dan memunculkan perilaku narsistik karena dorongan faktor dari teman sebaya yang juga memainkan aplikasi tersebut. Faktor internal yang membuat dirinya memiliki perilaku narsistik hal tersebut ada dalam kesesuaian 8 indikator antara lain kesesuaian pola perfasiv, kesesuaian perasaan grandiose, kesesuaian terpreokupasi, kesesuaian keyakinan dirinya istimewa, kesesuaian minta dipuji, kesesuaian mengeksploitasi, kesesuaian kurang memiliki empati dan kesesuaian arogan. Indikator kesesuaian terbesar diantara delapan ada pada keinginan untuk mendapatkan pujian ketika seorang anak kecanduan bermain aplikasi Tiktok. Dampak yang ditimbulkan dari perilaku narsistik seperti kehilangan rasa empati, memaksa serta mudah marah membuat anak pecanadu aplikasi Tiktok kurang disenangi dalam lingkungannya. Demikian anak pecandu aplikasi Tiktok, sejatinya baik dirinya maupun dari pihak terdekatnya seperti keluarga tetap memikirkan kewajibannya sebagai seorang insan yang belajar.

\section{SARAN}

Perilaku narsistik dari anak pecandu aplikasi Tiktok hendaknya disikapi dengan bijak, mencari kegiatan yang merangsang sistem kerja motorik anak sebagai bentuk pengalihan dari rasa candu bermain aplikasi Tiktok. Perilaku narsistik pada anak pecandu aplikasi Tiktok memiliki faktor dan dampak yang dirasakan secara tidak langsung baik bagi pengguna aplikasi tersebut maupun lingkungan sekitar dari pengguna aplikasi tersebut. Diharapkan peran penting orang tua untuk menciptakan suasana hubungan yang lebih intens sehingga komunikasi yang dibangun menjadi lebih kuat. Orang tua juga memiliki peran untuk membuat alternatif kegiatan sebagai pengalihan dari kecenderungan bermain aplikasi Tiktok tanpa mengenal batas waktu hingga mengganggu porsi belajar sebagai peran siswa yang masih duduk di bangku sekolah. Pihak sekolah tentunya ikut andil dalam membantu dengan meningkatkan suasana belajar mengajar yang lebih relevan dengan kondisi sekarang hingga anak - anak tidak merasakan suasana kaku dan jenuh selama proses belajar mengajar, hal tersebut berguna bagi pihak guru Bimbingan dan Konseling yang nantinya akan berkaitan secara langsung dengan kondisi psikis siswa terutama pada anak yang dirinya memiliki perilaku narsistik agar mendapatkan penanganan yang sesuai.

\section{DAFTAR RUJUKAN}

Anwar, S. (2014). Pemahaman Individu (Observasi, Checklist, Interviu, Kuesioner, Sosiometri). Yogyakarta: Pustaka Pelajar.

Asmaul, C. P. (2017). Pengaruh Media Gadget Pada Perkembangan Karakter Anak. Dinamika Penelitian: Media Komunikasi Sosial Keagamaan Vol 17. No. 2 , 315-330.

Dhias. (2013). Perkembangan Keseimbangan pada Anak Usia 7s/d 12 Tahun Ditinjau dari Jenis Kelamin. Jurnal Media Ilmu Keolahragaan Indonesia , 25-29.

Durand, V. M., \& Barlow, D. H. (2007). Intisari Psikologi Abnormal Edisi Keempat. Yogyakarta: Pustaka Pelajar.

Engkus, d. (2017). Perilaku Narsis Pada Media Sosial di Kalangan Remaja dan Upaya Penanggulangannya. Jurnal Penelitian Komunikasi , 121-134. 
Erick, B. (2017). Aktivitas Fisik Olahraga untuk Pertumbuhan dan Perkembangan Siswa SD. Indonesia Journal of Primary Education Vol 1 No 1, 51-58.

Hurlock. (2017). Psikologi Perkembangan (Suatu Pendekatan Sepanjang Rentang Kehidupan). Jakarta: Erlangga.

Kalyon Ayse, d. (2016). The Relationship Between Self-Handicapping Tendency and Narcissistic Personality Traits, Anxiety Sensitivity, Social Support, Academic Achievement. The Journal Of Psychiatry and Neurological , 237-246.

Mahmud. (2011). Metode Penelitian Pendidikan. Bandung: Pustaka Setia.

Maufur, \& A, T. (2012). Studi Perilaku. Bandung: Bintang WarliArtika.

Nana, S. (2013). Tuntunan Penyusunan Karya Ilmiah. Bandung: Sinar Baru Algensindo.

Novi. (2017). Dampak Kecenderungan Narcisme Terhadap Self Esteem pada Pengguna Facebook Mahasiswa PGSD UNP. Jurnal Dimensi Pendidikan dan Pembelajaran, 25-30.

Nugraheni Hariyanti, W. S. (2016). Pengaruh Narsisme dan Job Stressor pada Perilaku Kerja Kontrak Produktif dengan Respon Emosional Negatif (Anger) Sebagai Mediator. Jurnal Bisnis \& Manajemen , 49 - 66.

Nurul, Z. (2009). Metodologi Penelitian Sosial dan Pendidikan (Teori - Aplikasi). Jakarta: Bumi Aksara.

Riyanto Theo, d. (2006). Majalah Psikologi Plus (Empati yang Menyembuhkan). Semarang: CV. Harapan.

Rudi. (2017). Studi Tentang Siswa yang Memiliki Sikap Narsisme dan Penanganannya Melalui Latihan Tanggung Jawab dalam Konseling Gestalt. Jurnal Konseling AndriMatapa , 142-148.

Saputro, K. (2012). Tingkat Kecenderungan Narsistik Pengguna Facebook. Journal of Social and Industrial Psychology, 41-46.

Sartika, Y. (2017). Parental Role Narcissicm in Constructing Self - Image In Joice Carol Oate's Short Story. Pusat Kajian Humaniora (Center for Humanities Studies) , 41-49.

Sugiyono. (2017). Metode Penelitian Kuantitatif, Kualitatif dan R\&D. Bandung : Alfabeta.

Susilowati. (2018). Pemanfaatan Aplikasi Tiktok sebagai Personal Branding di Instagram (Studi Deskriptif Kualitatif pada Akun@bowo_alpennliebe). Jurnal Komunikasi, 176185.

Utama, d. (2019). Panduan Praktis Menulis Artikel. Jakarta: Prenada.

Indah, (2018) . Asal - Usul Aplikasi Tiktok dan Perkembangannya di Dunia. Wajib Tahu! Diakses pada HYPERLINK "https://cewekbanget.grid.id/read/06893247/asal-usul-aplikasi-tik-tok-danperkembangannya-di-dunia-wajib-tahu?page=all"

https://cewekbanget.grid.id/read/06893247/asal-usul-aplikasi-tik-tok-dan-perkembangannyadi-dunia-wajib-tahu?page=all 21/03/2020 10.11

M. Ferdiansyah, (2020) . Jumlah Unduhan Tiktok Kalahkan Facebook dan Instagram. Diakses pada HYPERLINK "https://techno.okezone.com/read/2020/01/16/207/2153835/jumlahunduhan-tiktok-kalahkan-facebook-dan-instagram?page $=2 "$

https://techno.okezone.com/read/2020/01/16/207/2153835/jumlah-unduhan-tiktokkalahkan-facebook-dan-instagram?page $=2$ 21/03/2020 12.18

Cindy Cesilia, (2018) . Begini Sejarah Terbentuknya Tiktok . Diakses pada HYPERLINK "https://www.winnetnews.com/post/begini-sejarah-terbentuknya-tik-

tok\%2021/03/2020\%2010.22" https://www.winnetnews.com/post/begini-sejarahterbentuknya-tik-tok 21/03/2020 10.22

Desy Setyowati, (2019) . Melebihi Instagram, Pengguna Tiktok tembus 1,5 Milyar . diakses pada HYPERLINK "https://katadata.co.id/berita/2019/11/19/melebihi-instagram-penggunatiktok-tembus-15-miliar" https://katadata.co.id/berita/2019/11/19/melebihi-instagrampengguna-tiktok-tembus-15-miliar 21/03/2010 11.44

Lautan IT, (2018) . Dampak Positif dan Negatif dari Tiktok, Membangun Digital Literasi. Diakses pada HYPERLINK "https://www.lautan-it.com/2018/05/dampak-positif-dan-negatif-daritiktok.html" https://www.lautan-it.com/2018/05/dampak-positif-dan-negatif-daritiktok.html 22/03/2020 11.44 
Karja, (2020) . 'Narcissistic Personality Disorder', Si Haus Pujian dan Merasa Paling Hebat . Diakses pada HYPERLINK "https://kumparan.com/karjaid/narcissistic-personalitydisorder-si-haus-pujian-dan-merasa-paling-hebat-1spYfRJwhAw/full" https://kumparan.com/karjaid/narcissistic-personality-disorder-si-haus-pujian-danmerasa-paling-hebat-1spYfRJwhAw/full 02/06/2020 08.01 